\title{
Environmental Impact from River Damming for Hydroelectric Power Generation and Means of Mitigation
}

\author{
Ash Kumar Rai
}

\begin{abstract}
Nepal is rich with inland water resources and has great potential for electricity power generation. Hydropower is one of the most sustainable national income sources to increase the nation's GNP. Relatively few water resources are under utilization, however, although some lakes in Pokhara valley and the Kulekhani storage type hydropower reservoir are successful in supporting multipurpose usage, combining electric power generation, irrigation and aquaculture. The Kaligandaki hydropower system is run of river, thus not feasible for cage fisheries; instead, it produces fingerlings of indigenous riverine fish for release into the river.

The impoundments after damming the rivers adversely impact both fish biodiversity and local fishing communities. Ecosystem change destroys feeding as well as breeding grounds, with a resultant loss of fish species. Where the movement of migratory fish up and down river is affected by hydropower development, fish hatcheries near the dam sites or fish ladders for fish movement should be considered as mitigation options. Local user groups and other stakeholders should be involved in decision-making, to keep good relations concerning peoples' livelihoods and the sustainability of aquatic resources. River systems should be thoroughly studied jointly with concerned agencies (e.g., electricity, irrigation and fisheries authorities; and local authorities) during formulation and application stages of hydroelectric power development projects.
\end{abstract}

Key words: River damming, power generation, biodiversity, fisheries, impact adversely, mitigation

Inland water resources are the most important natural resources of the Nepal Himalaya. Nepal is the second richest country in inland water resources in the world, possessing about $2.27 \%$ of the world water resources (CBS 2005). About 5\% of the total surface area of the country is covered by water (Bhandari 1992). The major sources of water are glaciers, snowmelt from the Himalayas, rainfall, and ground water. Out of 818,500 ha of total water surface area, there are about 6,000 rivers including rivulets and tributaries totaling about 45,000 $\mathrm{km}$ in length and covering 395,000 ha (DOFD 1961/62). The rivers, rivulets and tributaries play a very important role covering an estimated $48.3 \%$ of total water surface area. The riverine water resources are the nation's precious property, if properly utilized. Compared with other ecosystems, the aquatic life in this system is the most threatened biological diversity component. Most of the people use the world's river resources for food and recreation, and fishing is very important in the livelihoods and diets of the poor, providing an inexpensive source of animal protein and essential nutrients not available from other sources. Inland fisheries are generally less valued in terms of contribution to food security, income generation and ecosystem, but help greatly to highlight the complex contributions to rural livelihoods.

\section{River systems and riverine fisheries management}

Rivers provide substantial social as well as economic benefits to a large number of the people. The river fisheries provide a source of food and employment to sustain livelihoods, particularly of the rural poor. Most fisheries are of national economic importance and are crucial to local and regional food security, but they remain undervalued due to lack of proper management. Rivers are in an endangered position and suffer considerably due to human activities, including damming and catchment disturbances. Large rivers significantly support the earth's aquatic biodiversity. Migratory fish species are vulnerable during their life cycle due to river damming, and about $20 \%$ of the world's fresh water fishes are estimated near extinction or in urgent need of conservation. Therefore, to sustain biodiversity and fisheries in rivers requires sustainable management both of habitats and systems of exploitation. For the management of large river fisheries, the concerned authorities should be involved in the planning before the damming of rivers for electricity generation, in order to maintain and conserve river fish, fisheries and their environment accordingly. Most river fisheries are not managed effectively due to insufficient funding and lack of stakeholder collaboration, and are sometimes vulnerable to over exploitation. Appropriate legislation must 
be formulated to encourage more responsible management of living aquatic resources and the fisheries that depend on them. In some areas the water quality, quantity, fish poisoning, electro-fishing and mechanisms for fish passage are the subject of legislation that should apply rightly to protect ecosystem diversity. In addition, the user groups should also be involved in management decisions.

\section{Use of water resources}

There are about 6,500 ha of pond area ( $0.8 \%$ of total water surface area) in Nepal used for aquacultures that, if properly managed, have the capacity to produce about 20,000 MT of fish per year (DOFD 2061/62). The rest of the water bodies of the nation are used for irrigation and electricity power generation. The water resource of lakes is estimated to be 5,00o ha (0.6\%) of the water resources in the country. Of that amount, about 1,00o ha, primarily in the lakes of Pokhara valley of Nepal's midhill region, are under multipurpose usage. Pokhara's Phewa lake is used for electricity power generation, irrigation and aquaculture, as well as recreation for tourists. The nearby lakes Begnas and Rupa are also used for irrigation, aquaculture and recreation. In these lakes, aquaculture mainly involves cage fish culture and open water fish stocking. More than 300 family members are engaged in about $23,700 \mathrm{~m}^{3}$ of fish cage aquaculture in these three lakes, producing $100 \mathrm{MT}$ of fish per year. The people are basically fishers by profession, and are landless or have very low land holdings. The major role in cage fish culture is played by women in these communities, which therefore benefit from the employment. The three lakes of Pokhara valley are good examples of the multipurpose use of large bodies of water, including cage fish and open water fish stocking.

The 220 ha Kulekhani reservoir, at an elevation $1430 \mathrm{msl}$, was constructed in 1982 by damming the Kulekhani river and its tributaries at Markhu, Makwanpur District, in the hills south of Kathmandu valley. This is the first large-sized reservoir constructed in Nepal for electricity power generation. It is a storage type of reservoir with a catchment area of $126 \mathrm{~km}^{2}$. It depends mainly on rainfall and water accumulated primarily during the monsoon season (June-September). (Despite its size, however, the annual run-off from the river and its tributaries is insufficient to meet electrical power demand.)

The Kulekhani reservoir is the first manmade reservoir in Nepal applying the cage fish aquaculture technology. The aquaculture component was implemented in 1984 by the Nepal government with assistance from IDRC, the Canadian International Development Research Centre (Rai 1989). The project assessed the feasibility of a fisheries development program by gathering in-depth information on the limnological/biological parameters, then helped establish the foundation for fisheries development programs in this and future storage type reservoirs. Storage type reservoir can get rich nutrients flows from surrounding villages and farms during rainfall, which in turn helps produce plankton, the natural food of such planktivorous fish species as silver carp (Hypophthalmichthys molitrix) and bighead carp (Aristichthys nobilis). The cage type aquaculture at Kulekhani provides job opportunities for the local people as part of the mitigation efforts following reservoir construction and loss of farmland. More than 210 farmers are engaged in the cage fish culture at Kulekhani using more than $32,000 \mathrm{~m}^{3}$ cages for table fish production, and more than $7,100 \mathrm{~m}^{3}$ of nursery and rearing cages for fingerling production. Altogether, more than $34,000 \mathrm{~m}^{3}$ production cages produce fish in excess of $136 \mathrm{MT} / \mathrm{year}$ at a rate of more than 4 $\mathrm{kg} / \mathrm{m}^{3}$ (Rai 1989).

The Kali Gandaki hydroelectric power system is one of the nation's largest high capacity run-of-the-river projects, at a capacity of 144 MW. It was constructed by impounding the Kali Gandaki river at Mirmi, Syangja District, in the central midhills region (EIA 1996). The Kali Gandaki project has adversely affected fish biodiversity and the fishing community, who depend on fishing for their livelihood. This reservoir is a run-of-the-river type, and aquaculture is not feasible to mitigate such negative impacts. Therefore, a fish hatchery was built near the project site for mass seed production of economically high value indigenous riverine fish species, to allow stocking both up and down river from the dam site, to mitigate the negative effects of the dam on the pre-existing fisheries and to provide new income generation opportunities to the local fisher community.

The fish hatchery is run jointly by NARC, the Nepal Agricultural Research Council and NEA, the Nepal Electricity Authority. To the degree this program is successful, then this technology can be applied to future run-of-the-river type reservoirs. Out of the 184 fish species documented in Nepal (Shrestha 1995; Shrestha \& Chaudhary 2003), 57 species have been recorded in the Kali Gandaki river (EIA 1996); of them, Sahar, Asla, Katle and Gardi are successfully being bred and stocked in the river each year, as project mitigation activities.

Fish propagation and stocking to mitigate or compensate for adverse effects of some activity within the water basins are some of the means to maintain or improve fish populations in the environment. Besides 
that, regular research work has been carried out to study the behavior, growth, reproduction and adaptability of local commercially important indigenous riverine fish species, and to develop techniques for environmentally friendly conservation and development in the dammed river systems. Such basic information should provide significant knowledge on the biodiversity of the river system and help develop appropriate fisheries management technologies.

\section{Hydroelectric power generation}

Hydroelectric power generation is one of the basic needs to increase the GNP of the country (EIA 1996). Because Nepal has abundant water resources, there is great potential to use water resources for the electricity development as a sustainable national income source. Nepal has built several dams for hydroelectricity and irrigation purposes. Some that were built for hydroelectricity power generation are at Pharping (500 kW), Sundarijal (900 kW), Panauti (2400 kW), Phewa (1088 kW), Dhankuta (240 kW), Gorkha (64 kW), Seti (1500 kW), Salleri (400 kW), Dhading (32 kW), Surnaiyagad (200 kW), Kali GandakiA (144 MW), Marsyangdi (69 MW), Kulekhani-1 (6o MW), Kulekhani-2 (30 MW), Khimti Khola (6o MW), Bhotekoshi (36 MW), and Modi Khola (14.8 MW) (Jha \& Chaudhary 2003). Water represents one of the main resource opportunity for developing electric power generation for Nepal's future economic development. Water availability in Nepal, however, is highly seasonal and unevenly distributed geographically, and while hydropower projects with storage reservoirs are economically viable they require huge capital investment.

\section{Impacts of dam construction}

The impoundments after damming the rivers adversely impact fish biodiversity and the economics of fishing communities that depend on fishing for their livelihood. Dams have contributed to better water storage, irrigation and energy production, but have led to changes in upstream and downstream species composition and, in some instances, to species loss. Between 1950 and 1990 in India and China, dams displaced over 26 million people (Karki 2000). In these countries, and in Nepal, dam construction has resulted in adverse impacts on river fauna such as dolphins and migratory fish species, and on local people such as Nepal's Majhi, fishing folk, who tend to receive inadequate compensation for land lost or also lack direct access to benefits from such dams.

Electrical power generation supports the development of the nation, but the river ecosystems suffer adversely, especially the maintenance of fish species, which were not considered in some of Nepal's earliest hydropower projects. The West Seti river system has been studied for hydroelectric power generation of 750 MW capacity, with a proposed 1,989 ha reservoir area (SMEC 2000). Asla (Schizothorax spp. and Schizothoraichthys spp.) is the dominant fish species in Seti River, and the migratory Sahar (Tor spp.) is also common in that area. Asla needs running water with high oxygenated water, but after damming the reservoir will have stagnant water where this species cannot survive. Sahar and Eels are long migratory fish that cannot move up and down after damming. Also note that Sahar spawns during rainy season and migrates upwards, but with the dam that migration will be blocked. The ecosystem will change and both feeding grounds and breeding grounds will be destroyed, leading to fish species loss. 7,876 people in 1003 households live around the reservoir, and will also be affected (SMEC 2000). Therefore, to minimise negative impacts and to address or redress any adverse impacts to the people and the ecosystem, holistic planning and management of dam construction should be adopted.

\section{Potential for aquaculture in the reservoir}

Manmade reservoirs in Nepal cover about 1,500 ha, comprising about $0.2 \%$ of the nation's water resources (DOFD 2061/62). As the number of reservoirs increases, it is projected that an estimated 78,000 ha more water surface area will be needed for hydropower generation and irrigation purposes (Pradhan 1987). The proposed hydroelectric power in West Seti River will create a 1,989 ha area in a storage-type reservoir. That reservoir will collect rich nutrients from the villages and farms during rainfall that, in turn, will promote plankton growth and the potential for development of planktivorous fish culture. As this occurs, new job opportunities will be created for local people living around the reservoir. At the same time, national fish production and per capita fish protein consumption will also increase. Poverty can be reduced and food security improved when smallholder farmers and subsistence fishers achieve higher levels of sustainable productivity. 
However, a fish hatchery is necessary near the dam site to breed and produce enough fingerlings for aquaculture activities as well as for economically important high value local fish species to stock the river for conservation. Fishing pressure is an increasing trend with globally increasing human populations. Meanwhile, fish populations are decreasing due to over fishing all over the world, and sea water is becoming polluted due to mixing with polluted drain out water. Fish demand is high but fish production low; to fill the gap the importance of aquaculture in inland water bodies cannot be overstated. More than 6,00o large and small rivers flow in Nepal, some of which have high potential for hydroelectricity power generation; and, those with storage type reservoirs can accommodate commercial aquaculture. At the same time, community-based management should be applied to develop both responsibility and ownership within the fisher community.

\section{Implementation approach for mitigation}

During project formulation and implementation phase, the joint involvement of the electricity authority, irrigation, fisheries, and other district authorities and local concerned persons can, together, develop a strong approach to minimizing the adverse effect from damming. Either a fish hatchery or fish ladder for seasonal fish migration, depending on the reservoir type, can be developed as a mitigation measure that is both cost effective and sustainable. Fish hatcheries are needed to study and breed the local fish of economically high value and to develop breeding technologies for producing fingerlings and stock. The local fishing community should have fishing rights and also the authority and responsibility for conservation of fish diversity and the aquatic environment. A marketing strategy is also required for selling fish products both inside and outside the country. The local district should also be benefited by the project, with $10 \%$ of the profit from electricity production dedicated for community development. Likewise, another $1 \%$ of the profit from electricity generation should be allocated each to local village development committees for fish and other biodiversity conservation and for environmental mitigation in the affected areas. A collective approach by resource users and the society at large will be effective for river maintenance and restoration of degraded rivers and their fisheries. In short, the fisheries sector should not run in isolation from the hydroelectricity sector, but should communicate with the public and other users of water resources for sustaining the program.

Ash Kumar Rai, PhD (Aquaculture), General Secretary, Resources Himalaya Foundation, Kumaripati, Lalitpur, Former Chief, Fisheries Research Division, Nepal.

Corresponding address: akrai@wlink.com.np

References

Bhandari, B., 1992, The current status of wetlands in Nepal, country report presented at the Asian Wetland Symposium (14-20 October 1990, organized by Ramsar Center, Japan), Otsu/Kushiro, Japan: Ramsar.

CBS, 2005, Statistical Year Book of Nepal, Kathmandu: Central Bureau of Statistics, Government of Nepal.

DOFD, 2061/62, Annual Progress Report, Kathmandu: Fisheries Development Directorate, Government of Nepal.

EIA (Kaligandaki 'A' Associates), 1996, Kali Gandaki 'A' Hydroelectric Project Detailed Design, Environment Impact Assessment, Kathmandu: KGA-Morrison Knudsen Corporation (USA), Norconsult International (Norway) and IVO International (Finland).

Jha, J. \& Chaudhary, R., 2003, Hydropower development and fish diversity, a paper presented at the Workshop on Hydropower Dams: Impact on Fish Biodiversity and Mitigation Approaches, Kathmandu.

Karki, S., 2000, Dams and Development: Translating Global Recommendations to National Agenda and Action in Nepal Water, Wetlands and High Mountains, Kathmandu, International Union for Conservation of Nature.

Pradhan, B.R., 1987, Potential of reservoir fisheries development in Nepal, a paper prepared for the Workshop on Reservoir Fishery Management and Development in Asia (23-28 th November), Kathmandu.

Rai, A.K., 1989, Final Progress Report (16 July 1984-31 December 1989), Inland Fisheries Project, Kathmandu: Fisheries Development Division, National Agricultural Research and Service Centre, Ministry of Agriculture, Government of Nepal.

Shrestha, J., 1995, Enumeration of the Fishes of Nepal, Kathmandu: Biodiversity Profiles Project, Government of Nepal and Government of Netherlands.

Shrestha, J. \& Chaudhary, R., 2003, Fish biodiversity in Kali Gandaki River: Before and after the dam construction, in Proceedings on Hydropower Dams: Impact on Fish Biodiversity and Mitigation Approaches, Kathmandu: Nepal Agricultural Research Council (NARC) and Nepal Electricity Authority (NEA).

SMEC (Snowy Mountain Engineering Company), 2000, West Seti Hydroelectric Project: Environmental Impact Assessment, vol. 1, Cooma, NWA, Australia: SMEC. 